Al-Manhaj: Journal of Indonesian Islamic Family Law, 1 (2), 2019: 97-113

ISSN: 2715-003; E-ISSN 2714-5514

DOI: http://dx.doi.org/10.19105/al-manhaj.v1i2.3078

\title{
Vis a Vis Konsep Ahli Waris Beserta Hak-Haknya Dalam Islam Dan Kitab Undang-Undang Hukum Perdata
}

\author{
Misnatun \\ (Institut Agama Islam Negeri Madura, Jl. Raya Panglegur \\ KM 04 Pamekasan-69311, Jawa Timur, Indonesia)
}

\begin{abstract}
Abstrak:
Menurut hukum BW harta peninggalan yang akan diwarisi oleh para ahli waris tidak hanya meliputi hal-hal yang bermanfaat berupa aktiva atau keuntungan, melainkan juga termasuk hutang-hutang si pewaris yang merupakan pasiva dari harta kekayaan yang ditinggalkan sehingga "kewajiban membayar hutang pada hakekatnya beralih juga kepada ahli waris". rumusan masalahnya adalah bagaimana Konsep Waris Dalam Hukum Islam? Bagaimana Konsep Waris dalam KUHPerdata? Konsep Waris dalam Hukum Islam adalah perbedaan perolehan bagian ahli waris antara laki-laki dan perempuan secara sababiyah maupun nasabiyah serta harta dibagikan setelah bersih dari pengurusan jenazah, hutang piutang pewaris sebagai pasiva dari harta peninggalan dan lainnya. Konsep Waris dalam KUHPerdata tidak mengenal harta asal dan harta perkawinan (harta gono gini). Karena harta warisan adalah kesatuan harta yang secara bulat dan utuh dalam keseluruhan yang akan berpindah dari tangan si peninggal harta kepada seluruh ahli warisnya (masih hidup). (According to BW law the inheritance that will be inherited by the heirs not only covers things that are useful in the form of assets or profits, but also includes the debts of the testator who are liabilities of the assets left behind so that "the obligation to pay the debt in essence also switches to the heirs ". the formulation of the problem is what is the concept of inheritance in Islamic law? What is the concept of
\end{abstract}

Available online at: http://ejournal.iainmadura.ac.id/index.php/almanhaj/index

Author correspondence email: jayaloka85@gmail.com 
inheritance in the Civil Code? The concept of inheritance in Islamic law is the difference between the acquisition of an heir's share between men and women in sababiyah and nasabiyah as well as assets distributed after clearing the remains of the corpse, the heirs receivable debt as liabilities from inheritance and other assets. The concept of inheritance in the Civil Code does not recognize the origin and marriage assets (gono gini assets). Because the inheritance is a unitary property that is unanimous and intact in its entirety which will move from the hands of the deceased estate to all of its heirs (still alive)).

\section{Kata Kunci:}

Kewarisan; Ahli Waris; Islam; KUH Perdata

\section{Pendahuluan}

Islam sebagai agama mempunyai pedoman ajaran yang mengatur segala urusan umatnya, baik berkaitan dengan masalah ibadah, mu'amalah, maupun hal lainny. Dalam artian bahwa Islam tidak hanya berbicara tentang hubungan manusia dengan tuhannya, tetapi juga berbicara tentang hubungan manusia dengan manusia dan hubungan manusia dengan alam dalam hali ini hubungan manusia dengan bangsa dan negaranya. Dalam aturan tersebut yang dijadikan pegangan utama oleh umat Islam adalah Al-Qur'an dan Hadits, kedua-duanya menjadi sumber yang paling otentik dalam mencipatakan sebuah aturan yang kemudian kita dapat mengistilahkannya dengan Hukum Islam.

Adapun wujud harta peninggalan menurut hukum perdata Barat yang tercantum dalam KUH Perdata (BW) meliputi "seluruh hak dan kewajiban dalam lapangan hukum harta kekayaan yang dapat dinilai dengan uang". Jadi harta peninggalan yang akan diwarisi oleh para ahli waris tidak hanya meliputi hal-hal yang bermanfaat berupa aktiva atau keuntungan, melainkan juga termasuk hutang-hutang si pewaris yang merupakan pasiva dari harta 
kekayaan yang ditinggalkan sehingga "kewajiban membayar hutang pada hakekatnya beralih juga kepada ahli waris". ${ }^{1}$

Dari sini timbul beberapa pertanyaan yakni : Bagaimana Konsep Waris Dalam Hukum Islam? Bagaimana Konsep Waris dalam KUH Perdata?

\section{Metode Penelitian}

Penelitian ini menggunakan pendekatan deskriptif kualitatif. Selain itu penelitian ini merupakan penelitian pustaka. Yang tak lain adalah serangkaian aktifitas yang bersinggungan dengan pengumpulan data pustaka, mencatat, dan membaca serta mengolah bahan koleksi perpustakaan saja tanpa memerlukan riset lapangan. ${ }^{2}$

Ada empat ciri utama penelitian pustaka (1) Peneliti berhadapan langsung dengan teks atau data angka dan bukan pengetahuan langsung dari lapangan atau saksi mata berupa kejadian, (2) Data pustkla berupa bahan siap pakai, (3) Data kepustakaan umunya lazimnya sumber sekunder. Dan (4) Kondisi bahan pustaka tidak dibatasi ruang dan waktu.

Sehingga dengan demikian sumber data utama penelitian pustaka dalam konteks ini adalah kitab-kitab, buku-buku yang berisi tentang kajian kewarisan terutama dengan perspektif hukum islam dan KUH Perdata. Teknik pengumpulan data kepustakaan adalah dengan editing, organizing dan melakukan analisis lanjutan untuk menemukan kesimpulan penelitian.

\section{Kajian Teoretik Kewarisan Menurut Hukum Islam}

\section{A. Pengertian Waris dan Hak-Haknya dalam Islam}

Waris dalam islam adalah faraidh betuk jamak dari faridah yang berasal dari kata fardu, yang mempunyai arti ketetapan,

\footnotetext{
1 Eman Suparman, Intisari Hukum Waris Indonesia, (Bandung: Armico, 1985), 23 lihat juga Erie Hariyanto, "BURGELIJK WETBOEK (Menelusuri Sejarah Hukum Pemberlakuannya Di Indonesia)," Al-Ihkam: Jurnal Hukum Dan Pranata Sosial 4, no. 1 (3 September 2013): 140-52.

2 Zed Mestika, Metode Penelitian Kepustakaan, (Jakarta: Yayasan Bogor Indonesia, 2004), 3.
} 
pemberian (sedekah). ${ }^{3}$ Sedangkan Dalam alqur'an fardu artinya sebuah kewajiban ${ }^{4}$ ketetapan ${ }^{5}$.

Berikut terkait definisi faraid kami mengutip dari sebagian pandangan ulama seperti Syekh Zainuddin bin Abd Aziz al-Malibary mengatakan faraidh adalah:

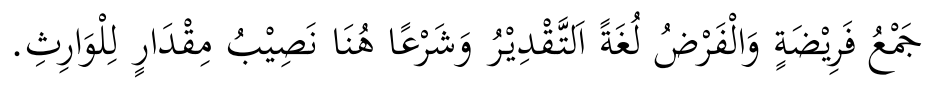

"Kata faraid bentuk jama dari faridah artinya yang difardukan. Fardu menurut arti bahasa adalah kepastian; sedangkan menurut syara dalam hubungannya di sini adalah bagian yang ditentukan untuk ahli waris." 6

Kemudian ilmu ini di ta'rifkan oleh para fuqaha' :

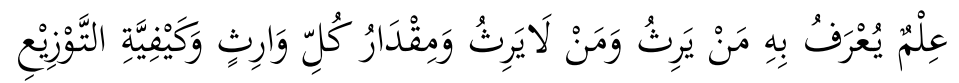

"Ilmu untuk mengetahui orang yang berhak menerima pusaka, dan orang yang tidak dapat menerima pusaka, dan kadar yang diterima oleh tiap-tiap waris dan cara pembagiannya."7

Maka kalau menurut penulis waris itu adalah ilmu pengetahuan yang membahas tentang penetapan harta pusaka oleh se peninggal bagi ahli warisnya yaitu orang-orang yang berhak menerima harta warisan.

Menurut istilah hukum di Indonesia di kutip dari pendapat Assyarbaini, ilmu Faraid ini disebut dengan "Hukum Waris" yaitu hukum yang mengatur tentang apa yang harus terjadi dengan harta kekayaan seseorang yang meninggal dunia. ${ }^{8}$ jadi harta yang ditinggalkan oleh si peninggal ini harus jelas jalannya apakah ada yang berhak dan siapa saja yang mempunyai hak atas harta peninggalan tersebut sesuai pembagian-pembagian yang ditentukan.

Kemudian definisi waris dalam Kompilasi Hukum Islam terdapat Dalam Pasal 171 ayat (a) juga dijelaskan "Hukum Kewarisan adalah hukum yang mengatur pemindahan hak pemilikan harta

${ }^{3}$ Louis Makluf, Al Munjid fi al- Lugah wa al I'lam, (Beirut: Dar al- Masyriq, 1986),. 577

${ }^{4}$ QS. Al-Qashash (28) : 85

5 QS. Al-Baqarah (2) : 197

${ }^{6}$ Zainuddin Ibn Abd Aziz al-Malibary, Fath al- Mu'in Bi Sarh Qurrah al-Uyun, (Maktabah wa Matba'ah, Semarang: Toha Putera, th), 95.

7 Zainuddin, Fath al- Mu'in.., 95

8 Al-Syarbini, Mugni al-Muhtaj, Juz III, ( Beirut: Dar al-Fikri,1984),. 3. 
peninggalan ( tirkah ) pewaris, menentukan siapa- siapa yang berhak menjadi ahli waris dan berapa bagiannya masing- masing" ${ }^{9}$

Hukum kewarisan merupakan ranah dari hukum kekeluargaan yang mempunyai peran penting yang mencerminkan tindakan suatu hukum dalam lingkup masayarakat. ${ }^{10}$ Dari beberapa definisi diatas dapat disimpulkan bahwa waris adalah kumpulan aturan hukum yang mengatur kewarisan tentang siapa saja yang berhak menerima waris dari orang yang meninggal (pewaris). Maka dapat kita fahami bahwa waris itu pengalihan harta dari seseorang yang sudah meninggal kepada orang yang masih hidup yang berhak mendapatkan hak-hak waris tersebut.

Dalam pandangan islam ahli waris itu terjadi karena dua segi yaitu dari segi sebab-sebab dan segi keturunan. Adapun dari segi sebab-sebab yaitu Ahli waris sababiyah dan Ahli waris nasabiyah, Sedangkan dari segi keturunan Ahli waris dapat dibagi kepada Ahli Waris Laki-Laki dan Ahli Waris Perempuan. ${ }^{11}$

1. Ahli Waris Dari Segi Sebab-Sebab

a. Ahli waris sababiyah

Ahli waris sababiyah ini terjadi karena perkawinan dalam kaitannya dengan hukum kewarisan Islam, berarti suatu hubungan perkawinan yang sah menurut hukum Islam. Apabila salah satunya suami-isteri meninggal dan meninggalkan harta warisan, maka masing-masing diantara mereka dapat saling mewarisi. Sebagaimana dalam firmannya QS An-Nisaa (4) : 12.

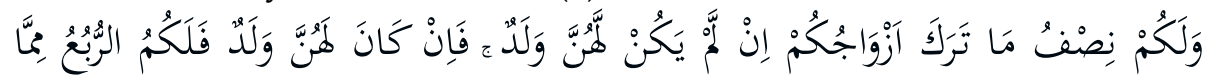

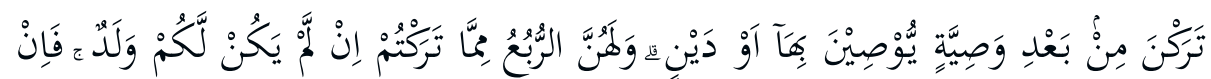

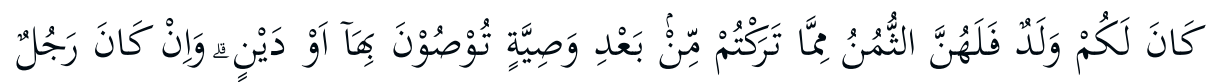

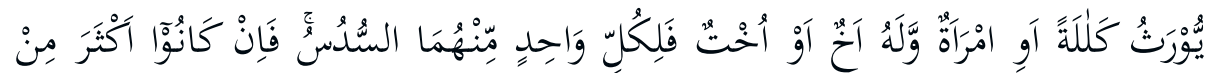

\footnotetext{
${ }^{9}$ Kompilasi Hukum Islam, Pasal 171 ayat( a) Tentang Hukum Kewarisan.

${ }_{10}$ M. Idris Ramulyo, Hukum Kewarisan Islam, (Jakarta: Ind-Hill, Co, 1984),.1.

11 Damrah Khair, Hukum Kewarisan Islam (Menurut Ajaran Sunni), (Bandar Lampung : Gunung Pesagi, 1993),. 49
} 


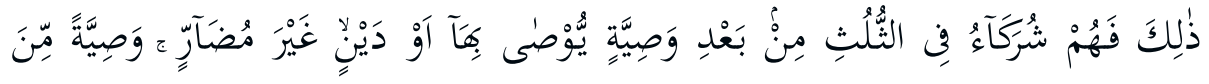

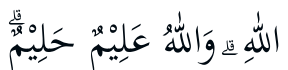

Artinya: Dan bagimu (suami-suami) seperdua dari harta yang ditinggalkan oleh isteri-isterimu, jika mereka tidak mempunyai anak. jika isteri-isterimu itu mempunyai anak, Maka kamu mendapat seperempat dari harta yang ditinggalkannya sesudah dipenuhi wasiat yang mereka buat atau (dan) seduah dibayar hutangnya. Para isteri memperoleh seperempat harta yang kamu tinggalkan jika kamu tidak mempunyai anak. jika kamu mempunyai anak, Maka Para isteri memperoleh seperdelapan dari harta yang kamu tinggalkan sesudah dipenuhi wasiat yang kamu buat atau (dan) sesudah dibayar hutang-hutangmu. ${ }^{12}$

b. Ahli Waris Nasabiyah.

Hubungan Ahli waris nasabiyah adalah ahli waris yang pertalian kekerabatannya kepada al-muwarris didasarkan pada hubungan darah ${ }^{13}$ yaitu hubungan nasab yang ditentukan oleh adanya kelahiran. Jika seorang anak lahir dari seorang ibu, maka ibu mempunyai hubungan kerabat dengan anak yang dilahirkan. Sebaliknya, bila diketahui hubungan antara ibu dengan anaknya maka dicari pula hubungan dengan laki-laki yang menyebabkan si ibu melahirkan. Jika dapat dibuktikan secara hukum melalui perkawinan yang sah penyebab si ibu melahirkan, maka hubungan kekerabatan berlaku pula antara si anak yang lahir dengan si ayah yang menyebabkan kelahirannya. ${ }^{14}$

Maka ditinjau dari hubungan nasab, ahli waris nasabiyah terbagi kepada tiga macam yaitu garis kebawah, keatas dan kesamping. ${ }^{15}$

1) Furu" Al-Mayit yaitu keturunan dari orang yang meninggal, garis lurus kebawah.

12 Departemen Agama RI, Al-Qur'an dan Terjemahnya, (Jakarta: Yayasan Penyelenggara Penterjeman / Pentafsir Al-Qur aan, 1971 ), 117.

${ }^{13}$ Ahmad Rofiq, Fiqih Mawaris, (Jakarta: PT. Raja Grafindo Persada, 2001),. 61

${ }^{14}$ Zainuddin Ali, Hukum Perdata Islam Indonesia, (Jakarta: Sinar Grafika, 2006), cet. I , 111.

${ }^{15}$ Firdaweri, Konsep Ahli Waris Menurut Islam dan Adat, Jurnal Asas, vol. 7, no. 2 Juli 2015,. 4. 
a) Anak laki-laki dan anak perempuan. Allah SWT menjelaskan dalam firman-Nya Q S An-Nisaa"e (4) : 11.

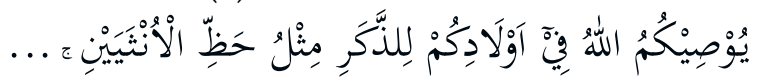

Artinya: "Allah mensyari'atkan bagimu tentang (pembagian pusaka untuk) anak-anakmu. Yaitu : bahagian seorang anak lelaki16 sama dengan bagahian dua orang anak perempuan ${ }^{17}$...."

b) anak laki-laki dari anak laki-laki yaitu cucu laki-laki sampai kebawah Karena lafaz auladukum dalam Q S An-Nisaa (4) : 11 diatas dapat dijadikan dalil bagi ahli waris ini.

c) Anak perempuan dari anak laki-laki yaitu cucu perempuan, atau. Hal ini dapat difahami dari hadis Rasul yang artinya:

“Dari Ibnu mas'ud, Nabi SAW telah menetapkan tentang bagian anak perempuan $1 / 2$, dan untuk anak perempuan dari anak laki-laki $1 / 6$, mencukupkan bagian menjadi $2 / 3$. Dan sisanya untuk saudara perempuan. ${ }^{18}$

2) Ushul al-Mayit yaitu orang-orang yang melahirkan orang yang meninggal dunia atau keturunan garis keatas, maka ahli warisnya adalah:

a) Ayah dan Ibu. Sesuai dalam firman-Nya Q S An-Nisaa"e (4) : 11.

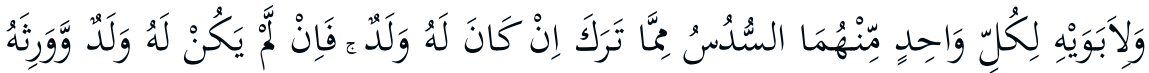

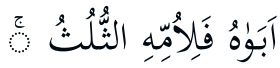

Artinya: “... Dan untuk dua orang ibu-bapa, bagi masing-masingnya seperenam dari harta yang ditinggalkan, jika yang meninggal itu mempunyai anak; jika orang yang meninggal tidak mempunyai anak dan ia diwarisi oleh ibu-bapanya (saja), Maka ibunya mendapat sepertiga. ${ }^{19}$

b) Datuk, atau kita sebut kakek shahih Yaitu ayah dari ayah, diatasnya ayah dari ayah lagi seterusnya sampai keatas tanpa diselingi

16 Bagian laki-laki dua kali bagian perempuan adalah karena kewajiban lakilaki lebih berat dari perempuan, seperti kewajiban membayar maskawin dan memberi nafkah

${ }^{17}$ Departemen Agama RI, al-Quran dan Terjemahnya,. 116.

18 Muhammad ibn Isma'il, Shahih Bukhari, (Maktabah Syamilah, tt), XX, hadis No. 6239,. 461

${ }^{19}$ Departemen Agama RI, Al-Qur'an Dan Terjemahnya,. 117. 
perempuan. Jika ada campuran perempuan maka ahli waris dinamakan kakek ghairu shahih. Kedudukan kakek shahih ini disebut sebagai ahli waris karena diterangkan "Dari Sulaiman bin Yasar, bahwa dia berkata: Umar bin Khathab menetapka bagian kakek seperenam. ${ }^{20}$

c) Nenek Shahihah, hubungan nasabnya tanpa diselingi oleh kakek. Kedudukan nenek ini sebagai ahli waris diterangkan oleh hadits Rasul SAW : Dari Ibnu Buraidah dari Bapaknya bahwa Nabi SAW menetapkan bagi nenek seperenam harta warisan jika tidak bersama dangan ibu. ${ }^{21}$

3) Al-Hawasyi

Hubungan nasab antara orang yang meninggal dunia dengan mereka itu adalah hubungan nasab ke arah menyamping. Al-Hawasyi diantaranya adalah saudara, paman beserta anak mereka masingmasing. Ahli waris Al-Hawasyi adalah:

a) Saudara Laki-Laki yang sekandung

b) Saudara Perempuan yang sekandung

c) Saudara Laki-Laki seayah

d) Saudara Perempuan yang seayah

e) Saudara Laki-Laki seibu

f) Saudara Perempuan seibu

g) Anak Laki-Laki dari saudara laki-laki sekandung

h) Anak Laki-Laki dari saudara laki-laki yang seayah

i) Paman sekandung

j) Paman sebapak

k) Anak laki-laki dari paman sekandung

1) Anak laki-laki dari paman seayah.22

Adapun dalil dari ahli waris al-hawasyi ini antara lain adalah Firman Allah QS An-Nisaa"e (4) : $176{ }^{23}$

${ }^{20}$ Malik Ibn Anas, Al-Muwaththa' (Maktabah Syamilah, tt), III,. 495

${ }^{21}$ Abu Dawud, sunan abi daud, (Maktabah Syamilah, tt), VII, hadis no. 2508,. 99.

${ }^{22}$ Asymuni A. Rahman dkk, Ilmu fiqih, (Jakarta: Departemen Agama, 1986),. 54. Lihat tulisan Akrom Khasani, Ahli Waris Nasabiyah dan Ahli Waris Sababiyah, Dipresentasikan dalam Kuliah Fiqih Mawaris, Dosen Pengampu Kurnia Muhajarah, M.S.I,. 3-4 


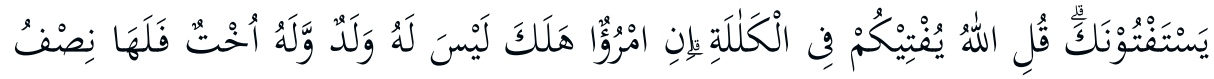

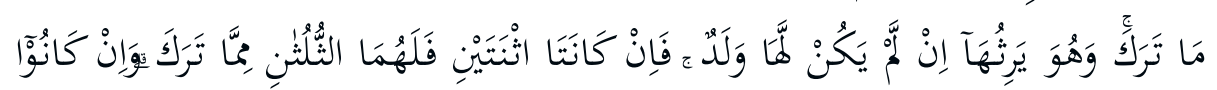

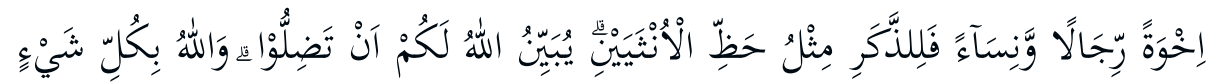

Artinya: Mereka meminta fatwa kepadamu (tentang kalalah). Katakanlah: "Allah memberi fatwa kepadamu tentang kalalah"2 (yaitu): jika seorang meninggal dunia, dan ia tidak mempunyai anak dan mempunyai saudara perempuan, Maka bagi saudaranya yang perempuan itu seperdua dari harta yang ditinggalkannya, dan saudaranya yang laki-laki mempusakai (seluruh harta saudara perempuan), jika ia tidak mempunyai anak; tetapi jika saudara perempuan itu dua orang, Maka bagi keduanya dua pertiga dari harta yang ditinggalkan oleh yang meninggal. dan jika mereka (ahli waris itu terdiri dari) saudara-saudara laki dan perempuan, Maka bahagian seorang saudara laki-laki sebanyak bahagian dua orang saudara perempuan. Allah menerangkan (hukum ini) kepadamu, supaya kamu tidak sesat. dan Allah Maha mengetahui segala sesuatu.

Firman Allah Q S An-Nisaa"e (4) : $12 .{ }^{25}$

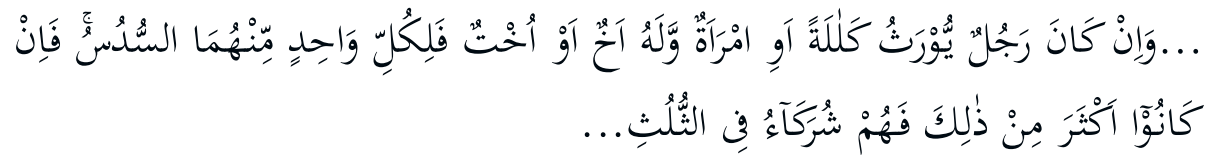

Artinya: jika seseorang mati, baik laki-laki maupun perempuan yang tidak meninggalkan ayah dan tidak meninggalkan anak, tetapi mempunyai seorang saudara laki-laki (seibu saja) atau seorang saudara perempuan (seibu saja), Maka bagi masing-masing dari kedua jenis saudara itu seperenam harta. tetapi jika saudara-saudara seibu itu lebih dari seorang, Maka mereka bersekutu dalam yang sepertiga itu.

2. Ahli Waris Dari Segi Keturunan Dibagi Kepada Ahli Waris Laki-Laki Dan Ahli Waris Perempuan

a. ahli waris laki-laki semuanya ada 15 yaitu anak laki-laki, bapak, suami, cucu laki-laki dari garis laki-laki, kakek dari ayah, saudara laki-laki sekandung, saudara laki-laki seayah, saudara laki-laki seibu, anak lakilaki saudara laki-laki sekandung, anak laki-laki saudara laki-laki seayah,

${ }^{23}$ Al-Qur'an Dan Terjemahnya,. 153.

${ }^{24}$ Kalalah Ialah: seseorang mati yang tidak meninggalkan ayah dan anak.

${ }^{25}$ Al-Qur'an Dan Terjemahnya,. 117 
paman dari ayah kandung, paman, dari ayah seayah, anak laki-laki paman sekandung, anak laki-laki paman seayah, orang laki-laki yang membebaskan budak. ${ }^{26}$

b. ahli waris perempuan semuanya ada 10 yaitu anak perempuan, cucu perempuan dari garis laki-laki, ibu, istri, saudara perempuan sekandung, nenek dari garis ibu, nenek dari garis bapak, saudara perempuan seibu, orang perempuan yang membebaskan budak. ${ }^{27}$

3. Rukun dan syarat Waris

Dalam kewarisan terdapat tiga rukun mewaris yaitu :

a. Pewaris (muwarrits) yaitu orang yang telah meninggal dan mewariskan harta kepada orang yang masih hidup dengan prinsip peralihan harta tersebut berlaku setelah pemilikharta meninggal.

b. Ahli waris (warits) yaitu seseorang yang punya pertalian darah atau perkawinan dengan pewarisnya.

c. Harta Warisan yaitu harta yang ditinggalkan oleh pewaris yang dialihkan kepada ahli warisnya. ${ }^{28}$

Adapun syarat-syarat warisan dalam islam dikategorikan ada tiga yaitu:

1) Orang yang memberi warisan (muwarris) jelas faktanya sudah meninggal dunia yang dapat dibuktikan dengan hukum kepeninggalannya. Maka jika pemberian harta tanpa ada kematian tidak dikatakan waris-mewarisi tetapi disebut hibah.

2) Ahli waris dalam keadaan hidup pada saat pewaris meninggal dunia ditunjukkan secara hukum. Orang yang masih hidup di sini adalah:

(a) Anak yang masih dalam kandungan ibunya dan yang mewariskan meninggal dunia

(b) Orang yang menghilang tanpa diketahui sudah meninggal atau tidak, hal perlu ada keputusan hakim yang menyatakan ia masih hidup, tetapi apabila tidakada kembali maka warisannya dibagikan kembali kepada ahli warisnya.

3) Ada hubungan kewarisan antara pewaris dan ahli waris yaitu hubungan nasab, hubungan pernikahan, hubungan perbudakan, dan hubungan karena agama Islam. ${ }^{29}$

26 Syifa Fauziah, Hukum Waris Dan Ketentuan Pembagian Harta Warisan Dalam Islam, (Bogor: Universitas Pakuan, 2016), . 15

27 Syifa Fauziah, Hukum Waris,. 16

28 Rachmadi Usman, Hukum Kewarisan Islam Dalam Dimensi KHI, (Bandung: CV. Mandar Maju, 2009), Cet. I,. 62 
4. Faktor Penghalang Waris Mewarisi

Adapun faktor yang menyebabkan terjadinya hak ahli waris terhalang menerima warisan dari al-muwarris terdiri dari tiga hal yaitu:

a) pembunuhan yaitu pembunuhan yang dilakukan oleh ahli waris kepada muwarris menyebabkan tidak dapat mewarisi harta peninggalan.

b) berbeda agama yaitu orang muslim tidak boleh menerima warisan dari orang kafir dan sebaliknya. ${ }^{30}$

c) perbudakan yaitu jika semata-mata bukan karena kemanusiaannya tapi karena budak (hamba sahaya).

5. Hak dan Kewajiban Ahli Waris

Sebelum ahli waris mendapatkan bagian haknya (harta waris) maka terlebih dahulu yang wajib dilakukan ahli wahris adalah menyelesaikan beberapa hak muwaris yaitu:

a) Zakat ; mengeluarkan zakatnya apabila telah sampai pada waktunya.

b) Belanja ; biaya selama peninggalan seperti biaya penguburan, kafan dan lain-lain.

c) Hutang ; jika muwarris masih ada hutang wajib di lunasi oleh ahli waris sebelum pembagian warisnya

d) Wasiat ; jika si peninggal berwasiat agar sebagian hartanya di bagikan maka wajib dilaksanakan. ${ }^{31}$

Sebagaimana yang terdapat dalam QS. An-Nisa' : 11 Allah berfirman:

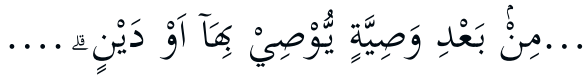

Artinya: Pembagian harta warisan itu dilaksanakan sesudah dikeluarkan wasiat yang diwasiatkan dan sesudah dibayar hutang". (An-Nisa' :11).32

\section{Ketentuan Kewarisan Dalam KUH Perdata}

Perlu diketahui bahwa KUH Perdata yang berlaku di Indonesia terdiri dari empat buku salah satunya adalah buku kedua

29 Amin Husein Nasution, Hukum Kewarisan: Suatu Analisis Komparatif Pemikiran Mujtahid dan KHI, ( Jakarta: PT. Raja Grafindo Persada, 2012), Cet. I, 71.

30 Mahmud Syalthut, Fiqih Tujuh Madzhab, terj. Abdullah Zakiy al-Kaaf, (Bandung:

CV Pustaka Setia, 2000),. 293

${ }^{31}$ M. Ali Hasan, Hukum Warisan dalam Islam, (Jakarta: Bulan Bintang, 1979),. 10

${ }^{32}$ Al-Qur'an Dan Terjemahnya,. 116. 
tentang kebendaan. sebagaimana yang dirumskan dalam Pasal 830 KUHPerdata yaitu dasar hukum waris adalah "Pewarisan hanya berlangsung karena kematian", maka dapat dipahami seseorang yang sudah meninggal dunia maka seluruh hak dan kewajibannya beralih kepada ahli warisnya. ${ }^{33}$ Yaitu orang yang meninggal dunia yang meninggalkan hartanya yang dimiliki semasa ia masih hidup.

A. Pitlo dalam bukunya" Hukum Waris Menurut Kitab Undangundang Hukum Perdata Belanda" memberikan batasan Hukum waris sebagai berikut: "Hukum waris, adalah kumpulan peraturan yang menagtur harta kekayaan si peninggal yaitu dari cara pengalihan hartanya dan akibat dari pengalihan bagi orang-orang yang mendapatkannya, baik dalam hubungannya antara sesama ahli waris atau mereka dengan pihak ketiga." 34

Oleh karena itu kita dapat berbicara tentang warisan apabila:

a. Ada orang yang meninggal

b. Ada harta yang ditinggalkan

c. Dan ada ahli waris (orang yang menerima warisan)

1. Faktor Penghalang Waris Mewarisi

Dalam KUH Perdata pasal 838, yang tidak dapat melakukan mewaris atau tidak berhak menjadi ahli waris adalah:

a. Seseorang yang telah dihukum karena di persalahkan membunuh pewaris atau mencoba membunuhnya.

b. Mereka dengan keputusan hakim dipersalahkan karena sudah menfitnah pewaris dengan pengaduan kejahatan yang dihukum lima tahun atau lebih berat.

c. Mereka yang telah melakukan kekerasan pada pewaris mencegah pewaris untuk mencabut surat wasiatnya.

d. Mereka yang telah membuat kegelapan, merusak dan memalsukan surat wasiat itu.

e. Mereka yang telah merusak, menggelapkan atau memalsukan surat pewaris. 35

33 Sudarsono, Hukum Waris dan Sistem Bilateral ( Jakarta: Rineka Cipta, 1991), Cet. I, 11.

34 A. Pitlo, Hukum Waris menurut Kitab Undang-Undang Hukum Perdata, terj. M. Isa Arief, (Jakarta: Intermasa, 1979),. 1.

35 Soetojo Prawirohamijoyo dan Marthalena Pohan, Hukum Waris, (Surabaya: Rinta, 1984), 134. 
2. Sebab-Sebab Mewarisi Menurut Hukum Perdata

Menurut Hukum Perdata untuk mendapatkan suatu warisan terdapat dua cara yaitu:

a. Sebagai ahli waris Undang-Undang (ab-intestanto) yaitu terdapat dalam Pasal KUH Perdata yaitu yang berhak menerima bagian warisan adalah para keluarga sedarah. Yang masih mempunyai hubungan darah baik hubungan darah mereka sah secara agama maupun diluar kawin dan suami isteri yang hidup terlama.

b. Sebagai ahli waris secara testeamentair terdapat dalam pasal 899 KUH Perdata. Testamentair yaitu seseorang yang menjadi ahli waris karena ditunjuk dalam suatu wasiat dalam artian pemilik kekayaan tersebut membuat wasiat yang di tunjuk kepada ahli warisnya dalam suatu wasiat. ${ }^{36}$

Kemudian menurut Undang-Undang ada plaatsveruulling yaitu pengisian tempat. Plaatsveruulling ini apabila ahli waris yang sudah berhak menerima warisan ternyata meninggal duluan dari si pewaris atau ada karena sesuatu yang mencegah dirinya menjadi ahli waris, maka yang berhak menjadikan pengganti ahli waris adalah anak-anaknya.

Berikut adalah mereka yang berhak menjadi pewaris ada empat golongan Menurut Undang-Undang pembagian waris. ${ }^{37}$

Golongan pertama;

a. suami isteri yang hidup terlama

b. anak dan keturunan anak.

Golongan kedua;

a. ayah ibu, saudara dan keturunan.

Golongan ketiga;

a. kakek dan nenek dari pihak bapak maupun ibu

b. orangtua kakek dan nenen seterusnya ke atas.

Golongan keempat;

a. paman dan bibi dari pihak bapak dan ibu

b. keturunan pamam dan bibi sampai derajat keenam

c. saudara dari kakek dan nenek beserta keturunannya sampai derajat keenam dari si peninggal. ${ }^{38}$

36 Effendi Perangin, Hukum Waris, (Jakarta: PT. Raja Grafindo Persada, 1997), 4 .

${ }^{37}$ Sudarsono, Hukum Waris.., 66 
Dengan adanya sistem Plaatsveruulling apabila golongan 1 meninggal dapat beralih kepada golongan ke dua, tiga dan empat secara otomatis. Terkait ahli waris yang ditunjuk dengan adanya wasiat dalam pasal $875 \mathrm{KUH}$ Perdata berbunyi: "Surat wasiat atau testament adalah sebuah akta berisi pernyataan seseorang tentang apa yang dikehendakinya terjadi setelah ia meninggal, yang dapat dicabut kembali olehnya". ${ }^{39}$

Pada dasarnya Undang-undang mengenal tiga macam bentuk surat wasiat. Sebagaimana yang sudah ditetapkan dalam pasal 931 KUH Perdata bahwa surat wasiat itu dapat dinyatakan dengan akta yang ditulis sendiri, olograpis, baik akta umum, maupun secara tertutup. Berikut kami uraikan secara ringkas.

a. Surat Wasiat Olograpis yaitu surat wasiat yang dibuat dan hasil tulisannya sendiri oleh testateur dan ditanda tangani sendiri sebagaimana yang diatur dalam pasal 932 KUH Perdata. Kemudian surat wasiat itu disetorkan kepada notaris dengan dihadiri dua saksi untuk disimpanya di protokol notaris dan membuat akta van depot dan ditanda tangani oleh testateur, saksisaksi dan notaris (Pasal 932 ayat 3) agar surat wasiat itu mempunyai kekuatan yang sama dengan surat wasiat umum yang dibuat didepan seorang notaris (Pasal 933 KUH Perdata).

b. Surat Wasiat Umum, yaitu surat yang dibuat dihadapan notaris oleh testeur. Surat wasiat umum ini merupakan bentuk testament yang yang sering ada dan dianjurkan sehingga ini merupakan yang paling umum. Notaris adalah orang yang ahli dalam bidang ini maka mempunyai kesempatan dan kewajiban untuk memberikan pengarahan supaya wasiat berjalan sesuai kehendak testateur.

c. Surat Wasiat Tertutup yaitu surat yang dibuat oleh testateur tanpa ada satu orangpun yang tahu. Kemudian surat itu diserahkan kepada notaris dalam keadaan tersegel. Tetapi notaris yang menerima surat wasiat tersebut harus membuat akta pengamatan dan dihadiri empat orang saksi.

${ }^{38}$ Effendi Perangin, Hukum Waris.,. 34

${ }^{39}$ Effendi Perangin, Hukum Waris.,. 232 
Sebenarnya dalam Undang-Undang masih mengenal satu surat lagi yaitu surat wasiat yang dibuat dalam keadaan darurat Selain tiga surat tersebut. (vide Pasal 946, 947, 948 B.W). 40

Dapat dipahami kalau pewarisan dalam perdata memberikan kebebasan kepada pewaris untuk berwasiat dengan menunjuk salah satu seorang baik keluarganya sendiri atau orang lain untuk menjadi pewaris. Pembagian warisan perdata berbeda dengan pewarisan islam, pewarisan dalam islam dapat berdiri sendiri diluar ahli waris.

3. Hak dan Kewajiban Ahli Waris

Adapun hak dan kewajiban yang beralih kepada ahli waris yaitu ruang lingkup kepemilikan harta kekayaan atau hak dan kewajiban saja yang bisa dinilai dengan money. Ciri khas yang ada dalam perdata maupun BW yaitu muncul hak kemutlakan dari ahli waris yang masing-masing dapat menuntut bagian dari harta warisnya. Jika sebagian ahli waris ada yang menuntut dipengadilan terkait bagian harta warisannya maka ahli waris yang lain tidak dapat menolaknya sesuai ketentuan pasal $1066 \mathrm{BW}^{41}$ yaitu:

a. Seseorang yang sudah mendapatkan bagian hak dari harta peninggalan itu maka tidak bisa dipaksa untuk membiarkan harta warisan dalam kondisi tidak dibagi-bagikan diantara merekaahli waris yang ada

b. Pembagian harta warisan peninggalan meskipun ada perjanjian yang melarang tetap dapat dituntut.

c. Untuk penagguhan dalam pembagian harta peningggalan hanya dapat dilakukan dalam beberapa waktu saja.

d. Perjanjian penangguhan tersebut pengikatannya hanya berlaku lima tahun saja, dan dapat diperbaharui apabila masih dikendaki dan disetujui oleh para pihak.

Kemudian untuk mendapatkan sebuah harta warisan dalam hukum perdata Indonesia ada dua cara yaitu. ${ }^{42}$

a. Menduduki sebagai ahli waris sesuai ketentuan Undang-Undang (ab intestato)

${ }^{40}$ J. Satrio, Hukum Waris, (Bandung, Alumni, 1990)., 185-186

41 A. Pitlo, Hukum Waris Menurut Kitab Undang-undang Hukum Perdata Belanda, Terjemahan M.Isa Arief, (Jakarta: Intermasa, 1979),. 10.

42 Eman Suparman, Hukum Waris Indonesia dalam Perspektif Islam, adat, dan BW, (Bandung: PT. Refika Aditama, 2014), IV,. 31 
b. Seseorang yang disebabkan karena ditunjuk sebagai wasiat dalam surat wasia (testamentair).

Sebagai seorang ahli waris, mereka berhak menuntut semua apapun yang merupakan harta peninggalan supaya dapat diserahkan kepada mereka (ahli waris), asal mereka mempunyai hak sebagai ahli waris sebagaimana yang sudah ditulis dalam Pasal 834 BW.

Yang dimaksud hak menuntut ahli waris disini, hanya tertentu saja yaitu pada seseorang yang ingin menguasai harta warisan dengan maksud untuk dapat memilikinya. Maka penuntutan ini tidak bisa diterapkan pada pelaksanaan wasiat (executeur testamentair), seorang kurator atas harta peninggalan yang tidak terurus dan penyewa dari benda warisan. 43

\section{Hasil Penelitian}

Berdasarkan data yang diperoleh disimpulkan bahwa dalam hukum Islam dibedakan bagian ahli waris antara laki-laki dan perempuan baik dari segi sababiyah maupun nasabiyah. Sedangkan dalam bagian masing-masing ahli waris, dalam pandangan Islam pembagian harta peninggalan akan dibagi setelah bersih dari pengurusan jenazah, utang-utang pewaris sebagai pasiva dari harta peninggalan dan lainya.

Kemudian dalam Sistem hukum waris BW (KUH Perdata) tidak mengenal harta asal dan harta perkawinan atau harta gono gini. Karena harta warisan dalam BW dari siapapun juga merupakan kesatuan yang secara bulat dan utuh dalam keseluruhan yang akan berpindah dari tangan si peninggal harta kepada seluruh ahli warisnya (masih hidup).

Hal ini berarti dalam sistem pembagian harta warisan dalam BW tidak dikenal perbedaan pengaturan atas dasar asal usul harta yang ditinggalkan oleh pewaris seperti yang diungkapkan dalam pasal 849 BW, “Undang-Undang tidak memandang akan sifat atau asal dari barang-barang dalam suatu harta peninggalan untuk mengatur pewarisan terhadapnya."

43 Ibrahim Hosen, Tinjauan Perbandingan Mazhab Fiqih Tentang Nikah, Talak, Rujuk, dan Kewarisan dalam Majalah Ihya 'Ulumudin,. 83 


\section{Penutup}

Dapat dipahami kalau pewarisan dalam perdata memberikan kebebasan kepada pewaris untuk berwasiat dengan menunjuk salah satu seorang baik keluarganya sendiri atau orang lain untuk menjadi pewaris. Pembagian warisan perdata berbeda dengan pewarisan Islam, pewarisan dalam islam dapat berdiri sendiri diluar ahli waris.

\section{Daftar Rujukan}

Ali, Zainuddin, Hukum Perdata Islam Indonesia, Jakarta: Sinar Grafika, 2006, cet. I

Al-Malibary, Zainuddin Ibn Abd Aziz, Fath al-Mu'in Bi Syarh Qurrah al-Uyun, Maktabah wa Matba'ah, Semarang: Toha Putera, tt.

Al-Syarbini, Mugni al- Muhtaj, Juz III, Beirut: Dar al-Fikri,1984

Anas, Malik Ibn, Al-Muwaththa' Maktabah Syamilah, tt, III

Dawud, Abu, Sunan Abi Dawud, Maktabah Syamilah, tt, VII

Departemen Agama RI, Al-Qur'an dan Terjemahnya, Jakarta: Yayasan Penyelenggara Penterjemah / Pentafsir Al-Qur an, 1971

Firdaweri, Konsep Ahli Waris Menurut Islam dan Adat, Jurnal Asas, vol. 7, no. 2 Juli 2015

Hariyanto, Erie. "BURGELIJK WETBOEK (Menelusuri Sejarah Hukum Pemberlakuannya Di Indonesia)." Al-Ihkam: Jurnal Hukum dan Pranata Sosial 4, no. 1 (3 September 2013): 140-52.

Hosen, Ibrahim, Tinjauan Perbandingan Mazhab Fiqih Tentang Nikah, Talak, Rujuk, dan Kewarisan dalam Majalah Ihya 'Ulumudin

Isma'il, Muhammad ibn, Shahih Bukhari, Maktabah Syamilah, tt

Khair, Damrah, Hukum Kewarisan Islam (Menurut Ajaran Sunni), Bandar Lampung: Gunung Pesagi, 1993

Makluf, Louis, Al Munjid fi al- Lugah wa al I'lam, Beirut: Dar alMasyriq, 1986

Mestika, Zed, Metode Penelitian Kepustakaan, Jakarta: Yayasan Bogor Indonesia, 2004

Rahman, Asymuni A. dkk, Ilmu fiqih, Jakarta: Departemen Agama, 1986

Ramulyo, M. Idris, Hukum Kewarisan Islam, Jakarta: Ind-Hill, Co, 1984

Rofiq, Ahmad, Fiqih Mawaris, Jakarta: PT. Raja Grafindo Persada, 2001

Suparman, Eman, Intisari Hukum Waris Indonesia, Bandung:

Armico, 1985 